\title{
PRELIMINARY STUDY REGARDING THE GROWTH AND YIELDING PROCESSES OF TWO ARONIA MELANOCARPA CULTIVARS IN THE PEDOCLIMATE CONDITIONS OF MARACINENI-ARGES AREA
}

\author{
Marinela Nicoleta Diaconescu Dinu ${ }^{1, *}$, Mihai Chivu ${ }^{2}$, Ivona Enescu (Mazilu) ${ }^{1,2}$, Sina Cosmulescu ${ }^{3}$ \\ ${ }^{1}$ University of Craiova, Horticulture Faculty, Doctoral School of Plant and Animal \\ Resources Engineering, Craiova, Romania \\ ${ }^{2}$ Research Institute for Fruit Growing Pitesti, Romania \\ ${ }^{3}$ University of Craiova, Horticulture Faculty, Department of Horticulture and Food
} Science, Craiova, Romania

\section{Current Trends in}

\section{Natural Sciences}

\begin{abstract}
The present paper studies the growth and fruiting processes of two Aronia melanocarpa cultivars, 'Melrom' and 'Nero', in the pedo-climatic conditions of the Muntenia (Arges) area, Romania. On average, over the whole experience, the 'Merlom' cultivar recorded a bush volume of $0.72 \mathrm{~m}^{3}$, annual vegetative growth of $0.38 \mathrm{~m}^{3}$, productivity of $1.88 \mathrm{~kg}$ of fruit per plant, and a ratio between fruit yield and the annual vegetative growth of $6.54 \mathrm{~kg} / \mathrm{m}^{3}$. In the 'Nero' $c v$., the volume occupied by the aerial part of the bush was $1.98 \mathrm{~m}^{3}$, with an annual vegetative growth of $0.43 \mathrm{~m}^{3}$, an yield of $3.14 \mathrm{~kg}$ of fruits per plant, and, reported to the annual vegetative, fruit production was $10.64 \mathrm{~kg} / \mathrm{m}^{3}$. Although the volume of the aerial part of the plant and the fruit production per plant were significantly higher in 'Nero' cultivar, 'Melrom' was noted by a larger ratio of fruit production to the unit volume of the aerial part of the plant, of $3.28 \mathrm{~kg} / \mathrm{m}^{3}$. As resulted from our study, both cultivars presented valuable yielding potential.
\end{abstract}

Keywords: chokeberry, yield, vegetative growth.

\section{INTRODUCTION}

Originally from eastern North America, Aronia melanocarpa was brought to the European continent, initially in Russia in the $19^{\text {th }}$ century, and attracted interest through the nutritional and therapeutic qualities of its fruits (Valcheva-Kuzmanova \& Belcheva, 2006). Aronia is, in general, a very undemanding plant, which allowed the shrub to spread easily in different growing environments. There are even mentions of its status as an invasive plant of spontaneous flora (Priede, 2009). Moreover, Bussières et al. (2008) mentioned black chokeberry weeds tolerance. It is robust and can easily tolerate temperatures up to $-30^{\circ} \mathrm{C}$. However, soil quality and the right location are important factors for optimal growth and high crop yields (Pandelea et al., 2021). Although resistant to cold, chokeberry needs light and heat during the growing season. Sunny exposure favors increased production and it influenced fruit quality (Tolic et al., 2017). Aronia is also suitable for areas with a less mild climate - windy areas and cultivation at altitudes up to 1000 meters above sea level, it does not present any problems. Mixed sand and clay soils proved to be ideal. High yields are obtained on humus-enriched soils, well-aerated and with a $\mathrm{pH}$ value between 6.0 and 6.5. Large 
yields with high-quality fruit are obtained when the right amounts and formulas of nutrients are applied at the right time (Nicola et al. 2020). However, McKay (2001) and Trinklein (2007) state that low levels of fertilizers tempered vegetative growth. The main aim of this study was to determine the effect of pedo-climatic conditions in Muntenia (Arges) area, Romania, on growth and fruit-setting processes in two Aronia cultivars.

\section{MATERIALS AND METHODS}

The present study follows the growth and fruiting processes of two Aronia melanocarpa cultivars, 'Melrom' and 'Nero' in the pedo-climatic conditions of the Muntenia (Arges) area $\left(44^{\circ} 54^{\prime} 11^{\prime \prime} \mathrm{N}\right.$ $24^{\circ} 52^{\prime} 29^{\prime \prime} \mathrm{E}$ ). The two experimental plots were established in the spring of 2011 ('Nero') and 2017 ('Melrom'), respectively at the planting distance 1.4 x $3 \mathrm{~m}$, grown as shrubs. The crop maintenance works consist of hand-removing weeds between plants and keeping grassy the interval between rows. Sprinkler irrigation is applied. The Aronia crop plots are located on a meadow terrace of the Argess River. As Nicola et al. (2020) described, the soil belongs to the class of wet phreatic aluviosol protisols, formed on fluvial deposits, with a loam-sandy granulometric composition, and is characterized by a strong to moderate acid reaction, low humus content, and low assimilable phosphorus content in the arable layer. The area is characterized by an average multiannual temperature of $10.0^{\circ} \mathrm{C}$, for the period October - September, and rainfall of $678.0 \mathrm{~mm}$. Indicators such as plants aerial part volume, annual volume increase (calculated as the difference between the volume occupied by the aerial part in autumn, at the cessation of vegetative growth and spring, before of vegetation entry), fruit production per plant, fruit production reported to the unit of the volume occupied by the aerial part, as well as the ratio between fruit production per plant and annual growth rate of the plant were assessed. For each cultivar, 10 plants in three replication were considered. The cultivar influence on studied indicators was performed by using the IBM SPSS (One way ANOVA and Simple Bivariate Correlation technique).

\section{RESULTS AND DISCUSSIONS}

Table 1 presents the indicators of the central tendency (mean, median, and mode) and those of value dispersion around the mean (extreme values, and standard deviation) that characterize the growth and fruiting processes of Aronia melanocarpa 'Melrom'and 'Nero' cultivars.

All assessed indicators were significantly influenced by cultivar and plant age (Table 2). Being in the fourth year of planting, the cultivar 'Melrom' had an average volume of the aerial part of the plant lower than the 'Nero' (in the tenth year of planting), respectively 0.72 , compared to $1.98 \mathrm{~m}^{3}$. Similarly, the fruit production of the 'Melrom' cultivar had an average value of $1.88 \mathrm{~kg} / \mathrm{plant}(3.84 \mathrm{t}$ / ha), with $46.51 \%$ lower than the production of the 'Nero' cultivar, of $3.44 \mathrm{~kg} /$ plant $(7,02 \mathrm{t} / \mathrm{ha})$, and the ratio between fruit yield and the annual vegetative growth was 6.54 for the 'Melrom' cultivar, below 'Nero' value (10.64 kg / m3). Similar to our study, Rousseau and Bergeron (2003) reported yields of approximately $2.4 \mathrm{~kg}$ of fruit per plant, which is the equivalent of $5.2 \mathrm{t} / \mathrm{ha}$, and Mckay (2001) stated that 5-year-old chokeberry plants can produce between 5 and $10 \mathrm{t} / \mathrm{ha}$ of fruit. Still, fruit yield per aerial part volume was significantly higher for 'Melrom'cultivar $(3.28 \mathrm{~kg} / \mathrm{m} 3)$ compared to 'Nero' (2.33 kg / m3). With significant differences, 'Nero' showed an annual increase in volume by $13.16 \%$ higher than the 'Melrom'cultivar. A $24.1 \mathrm{~kg}$ per plant yield was also reported by Strik et al. (2003) for 'Nero' (in the third year after planting), cultivated in Oregon, USA. Radanović et al. (2012) found similar plant sizes, but higher yield, $4200 \mathrm{~g}$ of fruits per plant in the third year for chokeberry grown on dystric cambisol, and lower plant sizes, with $79 \mathrm{~g}$ berries per 
Current Trends in Natural Sciences

Vol. 10, Issue 19, pp. 66-71, 2021

https://doi.org/10.47068/ctns.2021.v10i19.008

Current Trends in Natural Sciences (on-line)

ISSN: 2284-953X

ISSN-L: 2284-9521
Current Trends in Natural Sciences (CD-Rom)
ISSN: 2284-9521

ISSN-L: 2284-9521

plant for Aronia grown on calcareous chernozem in Serbia. In Kawecki and Tomaszewska (2006) study, in Poland, 15-year-old Aronia plants yielded a maximum of $15.5 \mathrm{~kg}$ fruits per bush when hand weeding as applied as weed management.

Table 1. Growth and fruiting processes indicators for A. melanocarpa 'Melrom'and 'Nero' cultivars

\begin{tabular}{|c|c|c|c|c|c|c|}
\hline Cultivar & & $\begin{array}{l}\text { Aerial } \\
\text { part } \\
\text { volume } \\
(\mathbf{m} 3)\end{array}$ & $\begin{array}{l}\text { Annual } \\
\text { vegetative } \\
\text { growth } \\
\text { (m3) }\end{array}$ & $\begin{array}{l}\text { Fruit yield } \\
\text { per plant } \\
(\mathrm{kg})\end{array}$ & $\begin{array}{l}\text { Fruit yield } \\
\text { per aerial } \\
\text { part volume } \\
(\mathrm{kg} / \mathrm{m} 3)\end{array}$ & $\begin{array}{l}\text { Fruit yield to annual } \\
\text { vegetative growth } \\
\text { ratio }(\mathrm{kg} / \mathrm{m} 3)\end{array}$ \\
\hline \multirow[t]{7}{*}{ 'Melrom' } & Average & 0.72 & 0.38 & 1.88 & 3.29 & 6.54 \\
\hline & Median & 0.7 & 0.39 & 1.83 & 3.14 & 6.18 \\
\hline & Mode & $0.46 a$ & 0.43 & $1.24 \mathrm{a}$ & $1.89 \mathrm{a}$ & $3.93 a$ \\
\hline & Standard dev. & 0.23 & 0.12 & 0.62 & 0.86 & 1.63 \\
\hline & $\mathrm{CV}(\%)$ & 31.32 & 30.87 & 32.8 & 26.01 & 24.87 \\
\hline & Minimum & 0.33 & 0.15 & 1.07 & 1.89 & 3.93 \\
\hline & Maximum & 1.33 & 0.63 & 3.14 & 5.22 & 9.74 \\
\hline \multirow[t]{7}{*}{ 'Nero' } & Average & 1.98 & 0.43 & 3.44 & 2.33 & 10.64 \\
\hline & Median & 2.01 & 0.43 & 3.6 & 2.29 & 10.57 \\
\hline & Mode & $.89 a$ & $.23 \mathrm{a}$ & 4.8 & 2.11 & $2.84 \mathrm{a}$ \\
\hline & Standard dev. & 0.66 & 0.17 & 1.58 & 0.8 & 4.13 \\
\hline & $\mathrm{CV}(\%)$ & 33.59 & 39.49 & 45.99 & 34.12 & 38.85 \\
\hline & Minimum & 0.11 & 0.03 & 0.3 & 0.72 & 2.84 \\
\hline & Maximum & 3.57 & 0.94 & 6 & 4.26 & 17.95 \\
\hline
\end{tabular}

Table 2. Cultivar influence on growing and fruiting indicators

\begin{tabular}{l|ccccc} 
Cultivar & $\begin{array}{c}\text { Aerial part } \\
\text { volume }(\mathbf{m 3})\end{array}$ & $\begin{array}{c}\text { Annual } \\
\text { vegetative } \\
\text { growth }(\mathbf{m 3})\end{array}$ & $\begin{array}{c}\text { Fruit yield } \\
\text { per plant }(\mathbf{k g})\end{array}$ & $\begin{array}{c}\text { Fruit yield } \\
\text { per aerial } \\
\text { part volume } \\
\text { unit }(\mathbf{k g} / \mathbf{m} 3)\end{array}$ & $\begin{array}{c}\text { Fruit yield per } \\
\text { annual } \\
\text { vegetative } \\
\text { growth }(\mathbf{k g} / \mathbf{m} 3)\end{array}$ \\
\hline Melrom & $0.72 \pm 0.23 \mathbf{b}$ & $0.38 \pm 0.12 \mathbf{b}$ & $1.88 \pm 0.62 \mathbf{b}$ & $3.29 \pm 0.86 \mathbf{a}$ & $6.54 \pm 1.63 \mathbf{b}$ \\
Nero & $1.98 \pm 0.66 \mathbf{a}$ & $0.43 \pm 0.17 \mathbf{a}$ & $3.44 \pm 1.58 \mathbf{a}$ & $2.33 \pm 0.79 \mathbf{b}$ & $10.64 \pm 4.13 \mathbf{a}$ \\
Sig. & 0.000 & 0.027 & 0.000 & 0.000 & 0.000 \\
Means followed by the same letters in the columns are not significantly different according to Duncan's multiple range test at $\mathrm{p} \leq 0.05$.
\end{tabular}

The correlations analysis (Table 3) shows, for both cultivars, a distinctly significant positive correlation of the plant aerial part volume with the annual vegetative growth ( $\mathrm{r}$ 'Melrom' $=0.893 * *$; $\left.\mathrm{r}^{\prime}{ }_{\text {Nero }}{ }^{\prime}=0.850 * *\right)$ and fruit production per plant $\left(\mathrm{r}^{\prime}{ }^{\prime}\right.$ Melrom' $\left.=0.726 * * ; \mathrm{r}^{\prime}{ }^{\prime}{ }^{\prime}{ }^{\prime}{ }^{\prime}=0.754 * *\right)$, as well as between the annual vegetative growth and fruit production per plant $\left(\mathrm{r}^{\prime}{ }^{\prime}\right.$ elrom $=0.783{ }^{*} * ; \mathrm{r}^{\prime}{ }_{\mathrm{Nero}}{ }^{\prime}=$ $0.577 * *)$. Positive correlations were found by Jeppsson (2000) between plant height and yield in black chokeberry 'Viking' cultivar. 
Current Trends in Natural Sciences

Vol. 10, Issue 19, pp. 66-71, 2021

https://doi.org/10.47068/ctns.2021.v10i19.008

Current Trends in Natural Sciences (on-line)

ISSN: 2284-953X

ISSN-L: 2284-9521
Current Trends in Natural Sciences (CD-Rom)

ISSN: 2284-9521

ISSN-L: 2284-9521

Table 3. Pearson correlations between growth and fruiting indicators for Aronia melanocarpa, Melro and 'Nero' cultivars

\begin{tabular}{|c|c|c|c|c|c|c|}
\hline Cultivar & & $\begin{array}{l}\text { Aerial } \\
\text { part } \\
\text { volume } \\
\left(\mathbf{m}^{\mathbf{3}}\right)\end{array}$ & $\begin{array}{l}\text { Annual } \\
\text { vegetative } \\
\text { growth } \\
\left(\mathbf{m}^{\mathbf{3}}\right)\end{array}$ & $\begin{array}{l}\text { Fruit yield } \\
\text { per plant } \\
\text { (kg/plant) }\end{array}$ & $\begin{array}{c}\text { Fruit yield } \\
\text { per aerial } \\
\text { part volume } \\
\left(\mathrm{kg} / \mathrm{m}^{3}\right)\end{array}$ & $\begin{array}{c}\text { Fruit yield to } \\
\text { annual vegetative } \\
\text { growth ratio } \\
\left(\mathrm{kg} / \mathrm{m}^{\mathbf{3}}\right)\end{array}$ \\
\hline \multirow[t]{4}{*}{ 'Melrom' } & $\begin{array}{l}\text { Aerial part volume } \\
\left(\mathrm{m}^{3}\right)\end{array}$ & 2 & $0^{2893}{ }^{* *}$ & $0.726^{* *}$ & -0.221 & -0.297 \\
\hline & \multicolumn{2}{|c|}{ Annual vegetative growth $\left(\mathrm{m}^{3}\right)$} & 1 & $0.783^{* *}$ & 0.021 & $-0.403^{\circ}$ \\
\hline & \multicolumn{3}{|c|}{ Fruit yield per plant (kg/plant) } & 1 & $0.494^{*}$ & 0.236 \\
\hline & \multicolumn{4}{|c|}{ Fruit yield per aerial part volume $\left(\mathrm{kg} / \mathrm{m}^{3}\right)$} & 1 & $0.721^{* *}$ \\
\hline \multirow[t]{4}{*}{ 'Nero' } & $\begin{array}{l}\text { Aerial part volume } \\
\left(\mathrm{m}^{3}\right)\end{array}$ & 1 & $0.850^{* *}$ & $0.754^{* *}$ & -0.339 & -0.006 \\
\hline & Annual vegetative $g$ & owth $\left(\mathrm{m}^{3}\right)$ & 1 & $0.577^{* *}$ & $-0.402^{*}$ & -0.281 \\
\hline & \multicolumn{3}{|c|}{ Fruit yield per plant (kg/plant) } & 1 & $\mathbf{0 . 3 3 0}$ & $0.564^{* *}$ \\
\hline & \multicolumn{4}{|c|}{ Fruit yield per aerial part volume $\left(\mathrm{kg} / \mathrm{m}^{3}\right)$} & $\mathbf{1}$ & $0.850^{* *}$ \\
\hline
\end{tabular}

According to Figure 1, plants of the 'Nero' cultivar in which the annual volume increase registers low values also have reduced fruit productions. Vegetative growth and fruit production increase simultaneously so that most of the plants showed high values for both indicators, as can be seen from the concentration of the cloud of points in the graph. This means that the plant invests in both growth and fruiting.

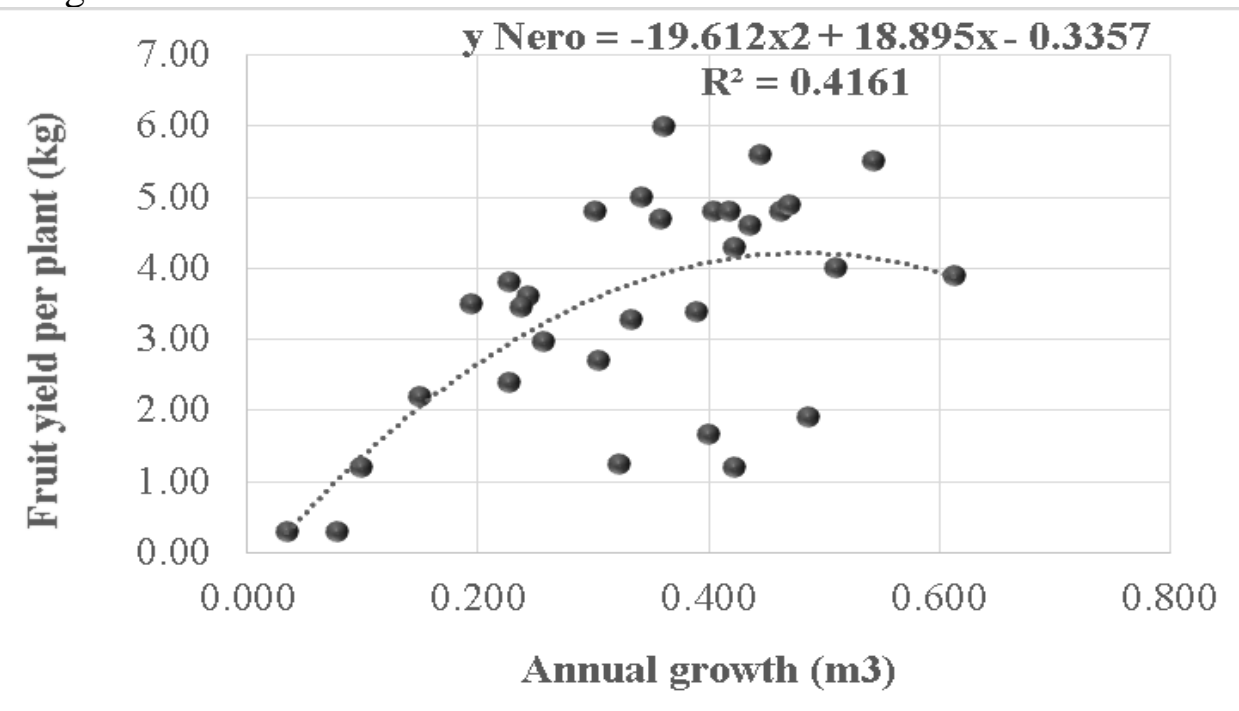

Figure 1. The correlation between the annual volume increase of plants and the production of fruits per plant, represented by the regression curve, for 'Nero' cultivar 


\section{Current Trends in Natural Sciences}

Vol. 10, Issue 19, pp. 66-71, 2021

https://doi.org/10.47068/ctns.2021.v10i19.008

Current Trends in Natural Sciences (on-line)

Unlike 'Nero', in the cultivar 'Melrom' (Figure 2) most plants fitted in the area of the graph characterized by below-average vegetative growth and low fruit production, as can be seen from the concentration of point clouds (left, bottom). Fruit production in this case tends to increase with the increase in the volume of the bush at a higher rate as the increase in volume occurs, as shown by the slope of the graph.

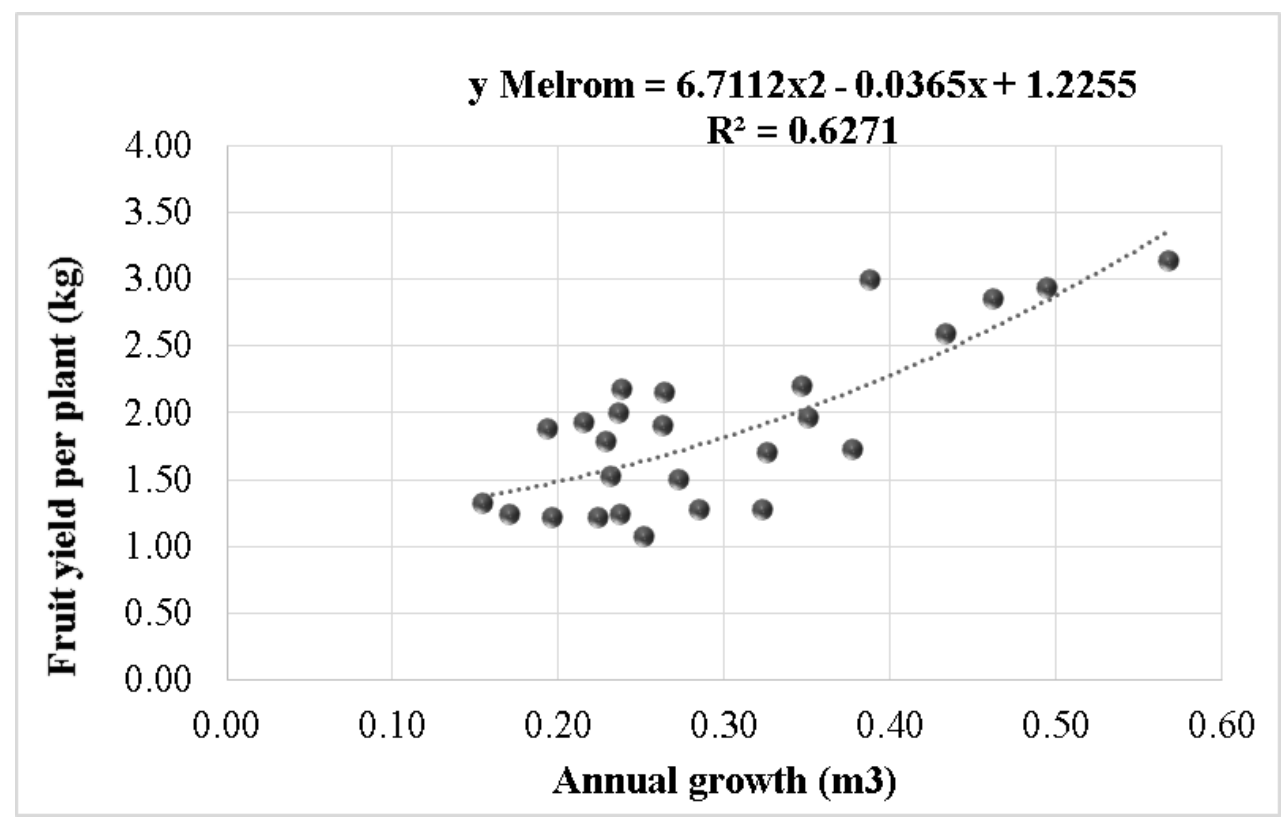

Figure 2. The correlation between the annual increase in plant volume and the production of fruits per plant, represented by the regression curve, for 'Melrom'cultivar

\section{CONCLUSIONS}

The two cultivars studied in this paper presented, in the pedoclimatic conditions in the Muntenia (Arges) area, growth and fruiting potential that falls within the limits mentioned in the literature, being, at the same time, valuable sources of fruits recognized for their nutritional qualities and biological activity content.

\section{ACKNOWLEDGEMENTS}

We would like to thank the Research Institute for Fruit Growing Pitesti for the plant material provided to us and for hosting this study.

\section{REFERENCES}

Bussieres, J., Boudreau, S., Clément-Mathieu, G., Dansereau, B., Rochefort, L. (2008). Growing black chokeberry (Aronia melanocarpa) in cut-over peatlands. HortScience, 43(2), 494-499.

Kawecki, Z., Tomaszewska, Z. (2006). The effect of various soil management techniques on growth and yield in the black chokeberry (Aronia melanocarpa Elliot). Journal of Fruit and Ornamental Plant Research, 14, 67.

McKay, S.A. (2001). Demand increasing for Aronia and elderberry in North America. New York Fruit Quarterly, 9(3), 2-3.

Nicola, C., Florea, A., Chițu, E., Butac, M. (2020). Evaluation of the biochemical quality of Aronia melanocarpa fruits in the conditions of southern Romania, under the influence of fertilization. Scientific Papers-Series B, Horticulture, 64(1), 147-154. 


\section{Current Trends in Natural Sciences}

Vol. 10, Issue 19, pp. 66-71, 2021

https://doi.org/10.47068/ctns.2021.v10i19.008

Current Trends in Natural Sciences (on-line)

Pandelea, G., Calinescu, M.F., Enescu (Mazilu) I.C., Stefan D.S. (2021). The influence of some composts on the growth and fruiting processes in the species Aronia melanocarpa (Michx.) Elliot. U.P.B. Sci. Bull. Series B, 83(1), 101112.

Priede, A. (2009). Factors determining the distribution of Aronia prunifolia, an emerging invasive plant species in Latvia. Acta Biol. Univ. Daugavp., Suppl. 2, 49-59.

Radanović, S.D., Antić-Mladenović, B.S., Sekulić, Đ.P., Ninkov, M. J., Radanović, D.B. (2012). Initial growth and yield of the black chokeberry (Aronia melanocarpa) grown on the dystric cambisol and calcareous chernozem soils and mineral composition of its fruits. In Proceedings of the Seventh Conference on Medicinal and Aromatic Plants of Southeast European Countries, pp. 284-290.

Rousseau, H., Bergeron, D. (2003). Native plant development program. Acta Horticulturae 626, 383-388.

Strik, B., Finn, C., Wrolstad, R. (2003). Performance of chokeberry (Aronia melanocarpa) in Oregon, USA. Acta Horticulturae 626, 439-443.

Tolic, M.T., Krbavcic, I.P., Vujevic, P., Milinovic, B., Jurcevic, I.L., Vahcic, N. (2017). Effects of weather conditions on phenolic content and antioxidant capacity in juice of chokeberries (Aronia melanocarpa L.). Polish Journal of Food and Nutrition Sciences, 67(1), 67-74.

Trinklein, D. (2007). Aronia: a berry good plant. Missouri environment and garden. http://arnoldia.arboretum.harvard.edu/pdf/articles/1938.pdf

Valcheva-Kuzmanova, S.V., Belcheva, A. (2006). Current knowledge of Aronia melanocarpa as a medicinal plant. Folia medica, 48(2), 11-17. 